\title{
Molecular fingerprinting of the intestinal microbiota of infants in whom atopic eczema was or was not developing
}

Citation for published version (APA):

Penders, J., Stobberingh, E. E., Thijs, C., Adams, H., Vink, C., Van Ree, R., \& van den Brandt, P. A. (2006). Molecular fingerprinting of the intestinal microbiota of infants in whom atopic eczema was or was not developing. Clinical and Experimental Allergy, 36(12), 1602-1608. https://doi.org/10.1111/j.13652222.2006.02599.x

Document status and date:

Published: 01/01/2006

DOI:

10.1111/j.1365-2222.2006.02599.x

Document Version:

Publisher's PDF, also known as Version of record

Please check the document version of this publication:

- A submitted manuscript is the version of the article upon submission and before peer-review. There can be important differences between the submitted version and the official published version of record.

People interested in the research are advised to contact the author for the final version of the publication, or visit the DOI to the publisher's website.

- The final author version and the galley proof are versions of the publication after peer review.

- The final published version features the final layout of the paper including the volume, issue and page numbers.

Link to publication

\footnotetext{
General rights rights.

- You may freely distribute the URL identifying the publication in the public portal. please follow below link for the End User Agreement:

www.umlib.nl/taverne-license

Take down policy

If you believe that this document breaches copyright please contact us at:

repository@maastrichtuniversity.nl

providing details and we will investigate your claim.
}

Copyright and moral rights for the publications made accessible in the public portal are retained by the authors and/or other copyright owners and it is a condition of accessing publications that users recognise and abide by the legal requirements associated with these

- Users may download and print one copy of any publication from the public portal for the purpose of private study or research.

- You may not further distribute the material or use it for any profit-making activity or commercial gain

If the publication is distributed under the terms of Article $25 \mathrm{fa}$ of the Dutch Copyright Act, indicated by the "Taverne" license above, 


\title{
Molecular fingerprinting of the intestinal microbiota of infants in whom atopic eczema was or was not developing
}

\author{
J. Penders*, E. E. Stobberingh ${ }^{\dagger}$, C. Thijs ${ }^{*}$, H. Adams ${ }^{\dagger}$, C. Vink ${ }^{\dagger}$, R. van Ree ${ }^{\S}$ and P. A. van den Brandt* \\ ${ }^{*}$ Department of Epidemiology, Nutrition and Toxicology Research Institute Maastricht (NUTRIM), Maastricht University, Maastricht, The Netherlands, ${ }^{\dagger}$ Department of \\ Medical Microbiology, University Hospital of Maastricht, Maastricht, The Netherlands, ${ }^{\ddagger}$ Department of Epidemiology, Care and Public Health Research Institute \\ (Caphri), Maastricht University, Maastricht, The Netherlands and ${ }^{\S}$ Department of Experimental Immunology, Academic Medical Center, Amsterdam, The Netherlands
}

\section{Clinical and Experimental Allergy}

Correspondence:

John Penders, Department of

Epidemiology, Nutrition and Toxicology

Research Institute Maastricht (NUTRIM), Maastricht University, PO

Box 616, 6200 MD Maastricht, The

Netherlands.

E-mail: j.penders@epid.unimaas.nl

\begin{abstract}
Summary
Background The rise in atopic diseases has been linked to disturbances in the intestinal microbiota composition.

Objective The purpose of this study was to investigate the intestinal microbiota composition in infants in whom atopic (IgE-associated) eczema was or was not developing, using a molecular fingerprinting technique.

Methods Within a prospective birth cohort study, fecal samples have been collected at the infant's age of 1 month. Within the context of this cohort, we conducted a nested case-control study comparing fecal samples of 26 infants who became sensitized and developed eczema within the first year of life with 52 non-sensitized non-eczematous infants. The composition of the fecal samples was examined using PCR combined with denaturing gradient gel electrophoresis. Using real-time PCR, total bacterial counts and bifidobacterial counts were enumerated.

Results Neither total bacterial profiles nor the type and proportion of bifidobacteria in the feces were associated with the development of atopic eczema. The similarity of bacterial profiles was low; mean similarity was approximately 33\% in both infants with or without atopic eczema. The prevalence of one specific band in total bacterial profiles was significantly higher in infants with atopic eczema compared with controls (96\% vs. 71\%, $P=0.01$ ).

Identification of this band revealed that it represented Escherichia coli.

Conclusion Although no association was found between the development of IgE-associated eczema and the dominant gut microbiota as a whole or with the bifdobacterial microbiota, the association with $E$. coli indicates that differences in gut microbiota do precede the development of atopy.
\end{abstract}

Keywords atopic eczema, DGGE, intestinal microbiota, nested case-control, 16S rRNA Submitted 23 June 2006; revised 3 August 2006; accepted 19 September 2006

\section{Introduction}

Intestinal microorganisms have a major impact on the development and functioning of the intestinal immune system of the host, while the intestinal immune system regulates the colonization of the gut by these microorganisms. This interplay has been suggested to have a major influence on the host even beyond the intestines [1]. For example, the rise of atopic diseases has been linked to disturbances in the composition of the gut microbiota [2]. Differences in intestinal microbiota have been described between healthy and allergic children [3-5]. Furthermore, in prospective studies, it has been shown that the differences in the gut microbiota composition are already present before the development of allergic sensitization and symptoms [6, 7].

Bifidobacteria are generally considered to be healthbeneficial and have been associated with a lower risk of atopy [3, 4, 6, 7]. The effect of bifidobacteria seems, however, to be species-dependent. In vitro studies have shown that bifidobacterial species differentially affect the production of cytokines by dendritic cells and macrophages $[8,9]$. Furthermore, allergic infants have been reported to harbour a more adult-type bifidobacterium 
flora containing Bifidobacterium adolescentis, whereas healthy infants had high levels of the infant-type B. bifidum [10].

Most studies on the gut microbiota and atopy were based on the quantification of selected bacterial groups or species that are commonly present in the intestines. The following are some of the disadvantages of classical culturing techniques: samples require immediate processing and extensive expertise, and specialized equipment is needed to isolate strict anaerobes [11]. The introduction of molecular techniques to study the gut microbiota has overcome these problems, and using these techniques, it now gives us the opportunity to analyse frozen samples collected from large cohorts.

PCR combined with denaturing gradient gel electrophoresis (PCR-DGGE) is a genetic fingerprinting technique, which provides a pattern or profile of the genetic diversity in a microbial community. In this technique, it is not required for the bacteria or their sequences to be previously characterized [12]. In principle, PCR-DGGE can be used to distinguish two (bacterial) DNA molecules that differ from as little as a single-base substitution [13]. Murray et al. [14] used this technique to compare the gut microbiota of sensitized wheezy and non-sensitized nonwheezy infants aged 4 years. Although no differences were found between cases and controls, the authors concluded that further studies using molecular techniques are necessary to establish whether differences between fecal microbiota composition truly exist in younger allergic and non-allergic children with different allergic diseases [14].

In the present study, fecal samples collected at the age of 1-month post-partum of infants in whom atopic eczema was or was not developing within the first year of life were compared using PCR-DGGE.

\section{Material and methods}

\section{Subjects and samples}

Within the prospective KOALA Birth Cohort Study on the aetiology of allergic diseases, we conducted a nested case-control study. The design of the cohort has been described previously [15]. Briefly, from October 2000 to December 2002, 2834 pregnant women were recruited at 14-18 weeks of gestation. Information on perinatal determinants of the child's health as well as on hygiene, infections, nutrition, child rearing, other lifestyle characteristics and on atopic manifestations were collected for all members of the cohort by repeated questionnaires at 34 weeks of gestation and 3, 7, 12 months post-partum. In the second part of the cohort (those participants recruited from October 2002 onwards), parents were asked to collect a fecal sample at the infant's age of 1 month and to consent to collecting of capillary blood for determination of total and specific IgE at the infant's age of 1 year.

For this nested case-control study, the selection criteria were the availability of infant's feces and capillary blood, full term birth and no history of antibiotic use within the first month of life. From those infants who met these criteria, we selected infants who subsequently developed atopic eczema, and randomly selected twice as many control infants. Cases had to meet the following criteria: (1) having an itchy relapsing rash during the first year of life (parentally reported), excluding cases with only diaper rash, rash around the eyes and/or scalp scaling; and (2) being IgE sensitized ( $>1 \mathrm{IU} / \mathrm{mL}$ ) for cow's milk, hen's egg or peanut at the age of 1 year. Control subjects were randomly selected out of the infants without an itchy relapsing rash during the first year of life and without detectable specific IgE levels ( $<0.36 \mathrm{IU} / \mathrm{mL}$ ). Determination of specific IgE from capillary blood has been performed as described previously [16, 17], with adjustments made for testing in capillary blood [18].

\section{Collection of infant's feces}

To collect feces at the infant's age of 1 month, parents received a feces tube with spoon attached to the lid (Sarstedt, Nümbrecht, Germany), together with a sanitary napkin, an instruction form and a brief questionnaire (feces questionnaire). Parents collected a fecal sample by placing the sanitary napkin in the diaper (to prevent absorption of the feces by the diaper) and collect the feces out of the napkin into the collection tube and sent it, together with the questionnaire, immediately to our laboratory by post. At the laboratory, fecal samples were tenfold diluted in peptone-water (Oxoid CM0009, Basingstoke, UK) containing 20\% v/v glycerol (Merck, Damstadt, Germany) and stored at $-20{ }^{\circ} \mathrm{C}$ until analysis.

\section{DNA purification from feces}

$0.2 \mathrm{~mL}$ of the diluted feces was added to a $2-\mathrm{mL}$ vial containing approximately $300 \mathrm{mg}$ glass beads (diameter $0.1 \mathrm{~mm}$ ) and $1.4 \mathrm{~mL}$ of ASL-buffer from the QIAamp DNA Stool Mini Kit (Qiagen, Hilden, Germany). The bacterial samples were disrupted in a mini-bead beater (Biospec Products, Bartlesville, OK, USA) at 5000 r.p.m. for $3 \mathrm{~min}$. Subsequently, the bacterial DNA was isolated from the samples using the QIAamp DNA Stool Mini Kit, according to the instructions of the manufacturer. The DNA was eluted in a final volume of $200 \mu \mathrm{L}$.

\section{Denaturing gradient gel electrophoresis}

All primers used in the study are listed in Table 1. Primers 968-GC-f and 1401-r were used to amplify the V6 to V8 regions of bacterial $16 \mathrm{~S}$ rRNA. Bifidobacterium 
Table 1. Primers and probes used in this study

\begin{tabular}{lll}
\hline Primer/probe & Sequence $\left(5^{\prime}-3^{\prime}\right)$ & References \\
\hline $968-G C-f$ & CGCCCGGGGCGCGCCCCGGGCGGGGCGGGGGC & {$[19]$} \\
& ACGGGGGG-AACGCGAAGAACCTTA & {$[19]$} \\
$1401-\mathrm{r}$ & CGGTGTGTACAAGACCC & {$[19,20]$} \\
Bif-164-f & GGGTGGTAATGCCGGATG & {$[19,20]$} \\
Bif-662-GC-r & CGCCCGCCGCGCGCGGCGGGCGGGGCGGGGGCACGGGGGG- & {$[24]$} \\
& CCACCGTTACACCGGGAA & {$[24]$} \\
Bif-f & GCGTGCTTAACACATGCAAGTC & \\
Bif-r & CACCCGTTTCCAGGAGCTATT & {$[24]$} \\
Bif-pr & TCACGCATTACTCACCCGTTCGCC & {$[35,36]$} \\
Total-f & TCCTACGGGAGGCAGCAGT & {$[35,36]$} \\
Total-r & GGACTACCAGGGTATCTAATCCTGTT & \\
\hline
\end{tabular}

genus-specific PCR was performed using $16 \mathrm{~S}$ rDNA-targeted primers Bif-164-f and Bif-662-GC-r. A 40-bp GCclamp was attached to the $5^{\prime}$ end of primer 968-GC-f and Bif-662-GC-r (Table 1) in order to facilitate the analysis of the PCR products by DGGE.

PCR reactions were performed as described previously $[19,20]$, using the HotStarTaq polymerase kit from Qiagen. The reaction mixtures contained $1 \times \mathrm{PCR}$ buffer (Qiagen), $3 \mathrm{~mm} \mathrm{MgCl}, 0.2 \mathrm{~mm}$ of each dNTP, $0.2 \mu \mathrm{m}$ of each primer, $1.25 \mathrm{U}$ Taq polymerase and $5 \mu \mathrm{L}$ of appropriately diluted template DNA in a final volume of $50 \mu \mathrm{L}$. The PCR thermocycling programme with primers $968-\mathrm{GC}-\mathrm{f}$ and 1401-r was the following: $94^{\circ} \mathrm{C}$ for $5 \mathrm{~min} ; 35$ cycles of $94{ }^{\circ} \mathrm{C}$ for $30 \mathrm{~s}, 53^{\circ} \mathrm{C}$ for $20 \mathrm{~s}, 68^{\circ} \mathrm{C}$ for $40 \mathrm{~s}$ and $68{ }^{\circ} \mathrm{C}$ for $7 \mathrm{~min}$. The reactions were subsequently cooled to $5^{\circ} \mathrm{C}$. The annealing temperature was changed from 53 to $62^{\circ} \mathrm{C}$ for primers Bif-164-f and Bif-662-GC-r.

Analysis of PCR amplicons by DGGE was performed essentially as described previously [19, 21], using the DCode detection system (Bio-Rad, Hercules, CA, USA). Polyacrylamide gels ( $8 \% \mathrm{w} / \mathrm{v}$, acrylamide : bisacrylamide$37.5: 1)$ in $0.5 \times$ TAE with a denaturing gradient were prepared with a gradient mixer and pump. The following denaturing gradients were used: $45-65 \%$ for bacterial and 45-55\% for bifidobacterial PCR products. A 100\% denaturant corresponds to $7 \mathrm{~m}$ urea and $40 \%$ (v/v) formamide. PCR amplicons were separated by electrophoresis at a constant voltage of $85 \mathrm{~V}$ and a temperature of $60^{\circ} \mathrm{C}$ for $16 \mathrm{~h}$. The DNA fragments were visualized by $\mathrm{AgNO}_{3}$ staining, as described previously [22]. Identification of bacterial species represented in the bifidobacterial DGGE profiles was based on the comparison with an identification ladder consisting of control strains of $B$. breve, $B$. bifidum, B. infantis, B. longum and B. adolescentis. Identification of bands of interest in total bacterial profiles was done by elution of DNA fragments from the gels followed by sequencing [23]. Selected DGGE bands were cut out of the gel with a sterile scalpel followed by elution of the DNA by mechanically disrupting the gel slices and resuspension in $50 \mu \mathrm{L} \mathrm{H} \mathrm{H}_{2} \mathrm{O}$. Two microlitre of the eluted
DNA of each DGGE band was reamplified by using the conditions described above (using primers 968-GC-f and 1401-r), after which PCR products were analysed by DGGE, together with the amplicons of the original samples in order to verify that the correct bands were isolated. Upon confirmation, PCR products were purified and sequenced using primers 968-GC-f and 1401-r.

\section{Quantification of bifidobacteria in fecal samples}

For the enumeration of bifidobacteria and total bacterial counts, samples were subjected to a quantitative real-time PCR, as described previously [24]. Briefly, the $5^{\prime}$ nuclease chemistry was used for the quantification of bifidobacteria with primers Bif-f and Bif-r and probe Bif-pr. The SYBR-Green chemistry was used for the determination of total bacterial counts using primers total-f and total-r.

\section{Statistical analysis}

Total bacterial profiles were compared using the GelCompar II software (Applied Maths, St-Martens-Latem, Belgium). With this software, Dice's similarity coefficients were calculated, following the equation:

$$
S=[2 a /(b+c)] \times 100 \%
$$

where $b$ is the number of PCR-DGGE bands in subject 1 , $c$ is the number of PCR-DGGE bands in subject 2 and $a$ is the number of matching PCR-DGGE bands [25]. Comparing the bacterial profile of each case with every other case created a matrix of similarity coefficients; therefore, a mean similarity coefficient for cases could be calculated. This was done for controls also.

All the other statistical analyses were performed using SPSS for Windows, version 12.01. Demographic characteristics of cases and controls were compared using $\chi^{2}$ tests.

The number of bands for each individual in the total bacterial profile (band richness) was calculated as an indicator of diversity of the total microbiota. The mean 
number of bands (band richness) in the total bacterial profiles was compared between cases and controls using the Student $t$-test. Furthermore, bands (in total bacterial profiles) present in 20 or more infants were compared for their prevalence in cases and controls using the $\chi^{2}$ test.

The Mann-Whitney rank sum-test was used to compare bifidobacterial counts (expressed as proportion of total bacterial counts) between cases and controls. To test for differences in the prevalence of specific bifidobacterial strains, as shown in the bifidobacterial profiles, the $\chi^{2}$ test was used.

\section{Results}

Of the 646 infants who met the selection criteria (presence of feces, capillary blood, full term birth and no history of antibiotic use in first month), 26 infants had both developed eczema in the first year of life along with specific IgE antibodies against milk, hen's egg and/or cow's milk $(>1 \mathrm{IU} / \mathrm{mL})$. All these infants were included as cases in the present study. Of the 375 infants who had not developed eczema in the first year and had no detectable specific IgE antibodies in their blood, 52 were randomly selected as controls.

There were no statistically significant differences between cases and controls in gender, infant feeding, birth season and mode of delivery (Table 2). However, the cases more often had an allergic mother (self-reported doctor's diagnosed eczema, hayfever, asthma, pet and/or house dust mite allergy) compared with healthy infants (54\% compared with $14 \%, P=0.00$ ) and also, although not statistically significant, tended to have an allergic father more often (46\% compared with $27 \%, P=0.09$ ). To account for a potential confounding effect of parental atopic status, all following analyses were performed both unstratified and stratified for parental atopic status (at least one parent atopic vs. none parents atopic).

The number of bands in total bacterial profiles or band richness represents the number of bacterial species present in a fecal sample and thus the diversity of the microbiota. The band richness was similar in cases and controls (mean; 7.54 vs. 7.63 bands, $P=0.92$ ). Also after stratification on parental atopic status (data not shown), no

Table 2. Characteristics of study population

\begin{tabular}{llll}
\hline & Cases & Controls & $P$-value \\
\hline Boys & $17 / 26(65 \%)$ & $24 / 52(46 \%)$ & 0.11 \\
Excl breastfed & $21 / 26(81 \%)$ & $37 / 52(71 \%)$ & 0.36 \\
Birth season & - & - & 0.33 \\
Vaginal delivery & $20 / 26(77 \%)$ & $44 / 52(85 \%)$ & 0.40 \\
Mother allergic & $14 / 26(54 \%)$ & $7 / 52(14 \%)$ & 0.00 \\
Father allergic & $12 / 26(46 \%)$ & $14 / 52(27 \%)$ & 0.09 \\
\hline
\end{tabular}

difference in mean band richness between cases and controls was found.

Comparison of total bacterial profiles showed that similarities between individuals were low, with mean similarity coefficients of 32.5\% for cases and 33.7\% for controls.

Five bands in total bacterial profiles were present in 20 or more infants; these bands were tested for difference in prevalence between cases and controls. One of these bands was present in all except one of the cases and in only 37 of 52 controls $(96 \%$ vs. $71 \%, P=0.01)$. This association persisted after adjusting for parental atopic status. This particular band had a similar position on gel as did the Escherichia coli control band from the identification ladder (Fig. 1). Excising and sequencing of this band from several lanes confirmed that it represented a fragment that was derived from the genome of E. coli (Fig. 1). The prevalence of the other four bands was similar in cases and controls.

Bifidobacteria were detected in all infants and the proportion that bifidobacteria comprised of the total bacterial counts was not significantly different between cases (median 37.6\%, range $0.07 \%$ to $>99 \%$ ) and controls (median 56.9\%, range $0.001 \%$ to $>99 \%, P=0.66$ ). The proportion of bifidobacteria of total bacterial counts remained similar in cases and controls in stratified analyses on parental atopic status.

The prevalence of the different bifidobacterial species, as determined by bifidobacterium-specific DGGE, is shown in Table 3. $B$. breve was most frequently detected (36/78 infants), followed by B. bifidum (32/78 infants).

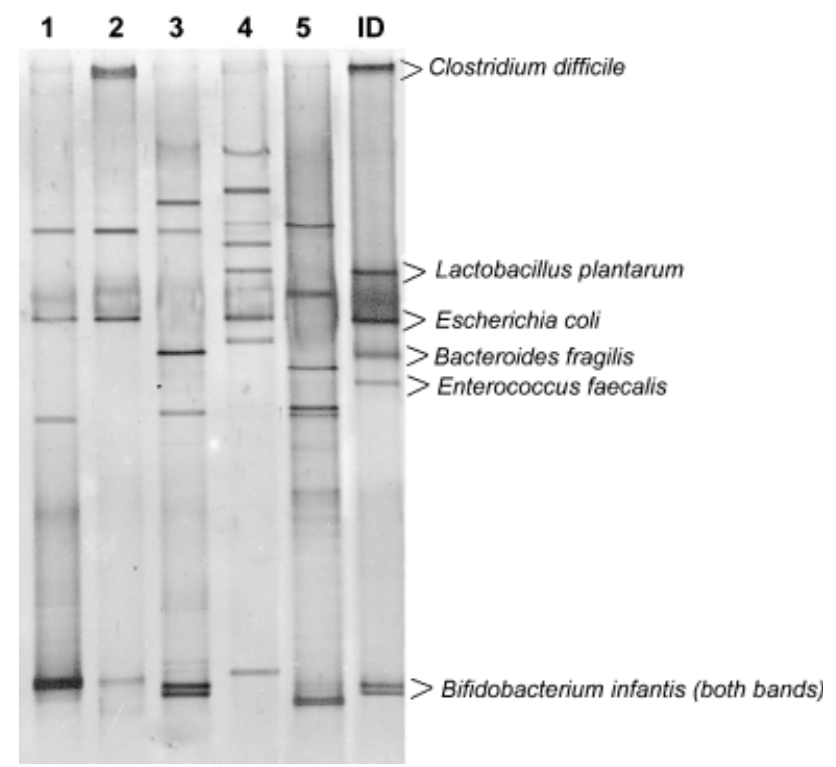

Fig. 1. An example of total bacterial profiles of fecal samples of 1month-old infants (1-5) and of an identification ladder (ID), as determined by denaturing gradient gel electrophoreses. Samples 1, 2 and 4 have a band corresponding to Escherichia coli. 
Table 3. The composition of the Bifidobacterium population in cases and controls

\begin{tabular}{lccc}
\hline Bifidobacterium species & Cases & Controls & $P$-value \\
\hline B. breve & $15(58 \%)$ & $21(40 \%)$ & $0.15^{*}$ \\
B. bifidum & $9(35 \%)$ & $23(44 \%)$ & $0.42^{*}$ \\
B. infantis/B. longum & $3(12 \%)$ & $10(19 \%)$ & $0.53^{\dagger}$ \\
B. adolescentis & $0(0 \%)$ & $3(6 \%)$ & $0.55^{\dagger}$ \\
\hline
\end{tabular}

$* \chi^{2}$ test.

${ }^{\dagger}$ Fisher’s exact test.

The prevalence of the different bifidobacterial species was similar between cases and controls (Table 3), and adjusting for parental atopic status did not change these results (data not shown).

\section{Discussion}

In the present study, PCR-DGGE was used to examine total bacterial profiles and the type and proportion of bifidobacteria in fecal samples of 1-month-old infants in whom IgE-associated eczema was or was not going to develop within the first year of life. Neither total bacterial profiles nor the type and proportion of bifidobacteria in the samples were associated with the development of IgEassociated eczema. E. coli was however significantly more often detected in infants who were going to develop atopic eczema compared with healthy controls.

Matching may increase efficiency if matching on strong risk factors is employed. Valid estimates can, however, also be obtained by controlling for important confounders in the analyses. Instead of matching, we therefore chose to perform stratified analysis on parental atopic status, the only population characteristic under study which differed between cases and controls. We found that this stratification did not change the results.

It has been suggested that if differences in gut microbiota composition truly exist in early life between children who go on to develop atopic sensitization compared with those who do not, it is possible that these differences are genetically determined [14]. As the association between E. coli and IgE-associated eczema in our study persisted after adjusting for parental atopic status, this explanation seems unlikely. Furthermore, as fecal sampling was conducted before the manifestation of atopic symptoms, we can conclude that differences in $E$. coli colonization precede the development of IgE-associated eczema.

Kirjavainen et al. [26] reported the number of $E$. coli in feces to be positively correlated with total serum IgE levels in infants with atopic dermatitis. Conversely, oral introduction of a non-enteropathogenic E. coli strain after birth has been shown to reduce the risk of developing allergic diseases in another study [27]. It seems therefore likely that the effects of $E$. coli are strain-dependent.
Interestingly, administration of probiotic E. coli strains in the intestine has been shown to decrease the presence of pathogenic bacterial strains [28], and to enhance the barrier defense against some pathogenic E. coli strains [29].

It has been argued that the impact of the indigenous microbiota on the development of the infant's immune system may not be dependent on specific microbial strains, but that continuing stimulation by the dynamic microbiota as a whole might override the importance of any individual strain or infection [30]. For instance, a high turnover of appropriate bacteria may provide such a continuous immune stimulation necessary to prevent atopy and atopic diseases [31]. A lower diversity of the bacterial microbiota could be related to a limited bacterial turnover, suggesting to reduce the stimulation of the immune system $[32,33]$. This would imply that atopic infants have a less diverse microbiota compared with healthy infants. However, we did not find that cases had a lower diversity (less bands) than controls. Total bacterial profiles of both atopic and healthy infants under study comprised on average seven to eight different bands indicating a relatively low diversity of the dominant intestinal microbiota. Indeed, it is known that infants at this young age have a relatively simple microbiota [34].

Another way to examine if the intestinal microbiota as a whole is involved in the development of atopic diseases is by looking at the total bacterial profiles. If infants in whom IgE-associated eczema is going to develop would have a predisposing microbial make-up in common early in life, this would be expressed in a high similarity index. Mean similarity coefficients in both atopic and healthy infants were low (approximately 33\% in both atopic and healthy infants), meaning each individual has a fairly unique bacterial profile already at this age, and we found no common bacterial profile among infants becoming atopic.

Although we did not find that the dominant microbiota as a whole (diversity and similarity) was associated with the development of IgE-associated eczema, it should be noted that by using PCR-DGGE only dominant species ( $>1 \%$ of total microbiota) can be visualized. Therefore, it cannot be excluded that differences exist in the number and profiles of minor species between infants in whom IgE-associated eczema was or was not going to develop.

Bifidobacteria have been associated with a lower risk of developing atopic diseases [3, 4, 6, 7]; furthermore, different bifidobacterial species have been shown to exert different effects on the immune system [8, 9], and were differently associated with atopic eczema [10], but not with IgE-associated wheeze [14]. We found no association between the proportion bifidobacteria of total counts or specific bifidobacterial strains and IgE-associated eczema. The infant-type bifidobacteria (B. breve and B. bifidum) were most frequently detected, whereas the adult-type $B$. 
adolescentis, which has previously been linked to allergy [10], was only detected in three healthy infants in our study.

In conclusion, we did not find an association between the dominant gut microbiota as a whole and IgE-associated eczema. Already at this young age each infant appeared to have a unique, although still simple, bacterial profile. Also, no association was found between the number of bifidobacteria or the type of bifidobacterial species and the development of atopy. The development of IgE-associated eczema was however associated with colonization by $E$. coli, indicating that differences in gut microbiota do precede the development of atopy. Larger differences may be found for those species that are not part of the dominant microbiota.

\section{Acknowledgements}

We thank Chantal Delnoy, Brigitte Winants and Karen Groot (blood collection), Cobie Martens and Willeke Hendrikx (data assistance), Astrid van Leeuwen (Sanquin, IgE determination), Dominique Goossens and Christel Driessen (assistance in PCR-DGGE) and last but not least all mothers and their infants, participating in the KOALA study.

\section{References}

1 Ouwehand A, Isolauri E, Salminen S. The role of the intestinal microflora for the development of the immune system in early childhood. Eur J Nutr 2002; 41:I32-7.

2 Noverr MC, Huffnagle GB. Does the microbiota regulate immune responses outside the gut? Trends Microbiol 2004; 12:562-8.

3 Watanabe S, Narisawa Y, Arase S et al. Differences in fecal microflora between patients with atopic dermatitis and healthy control subjects. J Allergy Clin Immunol 2003; 111:587-91.

4 Bjorksten B, Naaber P, Sepp E, Mikelsaar M. The intestinal microflora in allergic Estonian and Swedish 2-year-old children. Clin Exp Allergy 1999; 29:342-6.

5 Kirjavainen PV, Apostolou E, Arvola T, Salminen SJ, Gibson GR, Isolauri E. Characterizing the composition of intestinal microflora as a prospective treatment target in infant allergic disease. FEMS Immunol Med Microbiol 2001; 32:1-7.

6 Kalliomaki M, Kirjavainen P, Eerola E, Kero P, Salminen S, Isolauri E. Distinct patterns of neonatal gut microflora in infants in whom atopy was and was not developing. J Allergy Clin Immunol 2001; 107:129-34.

7 Bjorksten B, Sepp E, Julge K, Voor T, Mikelsaar M. Allergy development and the intestinal microflora during the first year of life. J Allergy Clin Immunol 2001; 108:516-20.

8 He F, Morita $\mathrm{H}$, Hashimoto $\mathrm{H}$ et al. Intestinal Bifidobacterium species induce varying cytokine production. J Allergy Clin Immunol 2002; 109:1035-6.

9 Young SL, Simon MA, Baird MA et al. Bifidobacterial species differentially affect expression of cell surface markers and cytokines of dendritic cells harvested from cord blood. Clin Diagn Lab Immunol 2004; 11:686-90.
10 He F, Ouwehand AC, Isolauri E, Hashimoto H, Benno Y, Salminen S. Comparison of mucosal adhesion and species identification of bifidobacteria isolated from healthy and allergic infants. FEMS Immunol Med Microbiol 2001; 30:43-7.

11 Furrie E. A molecular revolution in the study of intestinal microflora. Gut 2006; 55:141-3.

12 Muyzer G, Smalla K. Application of denaturing gradient gel electrophoresis (DGGE) and temperature gradient gel electrophoresis (TGGE) in microbial ecology. Antonie Van Leeuwenhoek 1998; 73:127-41.

13 Sheffield VC, Cox DR, Lerman LS, Myers RM. Attachment of a 40-base-pair G + C-rich sequence (GC-clamp) to genomic DNA fragments by the polymerase chain reaction results in improved detection of single-base changes. Proc Natl Acad Sci, USA 1989; 86:232-6.

14 Murray CS, Tannock GW, Simon MA et al. Fecal microbiota in sensitized wheezy and non-sensitized non-wheezy children: a nested case-control study. Clin Exp Allergy 2005; 35:741-5.

15 Kummeling I, Thijs C, Penders J et al. Etiology of atopy in infancy: the KOALA Birth Cohort Study. Pediatr Allergy Immunol 2005; 16:679-84.

16 Aalberse RC, Koshte V, Clemens JG. Immunoglobulin E antibodies that crossreact with vegetable foods, pollen, and Hymenoptera venom. J Allergy Clin Immunol 1981; 68:356-64.

17 Stallman PJ, Aalberse RC. Estimation of basophil-bound IgE by quantitative immunofluorescence microscopy. Int Arch Allergy Appl Immunol 1977; 54:9-18.

18 Stapel So, Eysink PE, Vrieze J, Aalberse RC. IgE testing in capillary blood. Pediatr Allergy Immunol 2004; 15:230-3.

19 Satokari RM, Vaughan EE, Favier CF, Dore J, Edwards C, de Vos WM. Diversity of Bifidobacterium and Lactobacillus spp. in breast-fed and formula-fed infants as assessed by $16 \mathrm{~S}$ rDNA sequence differences. Microb Ecol Health Dis 2002; 14:97-105.

20 Satokari RM, Vaughan EE, Akkermans AD, Saarela M, de Vos WM. Bifidobacterial diversity in human feces detected by genusspecific PCR and denaturing gradient gel electrophoresis. Appl Environ Microbiol 2001; 67:504-13.

21 Muyzer G, de Waal EC, Uitterlinden AG. Profiling of complex microbial populations by denaturing gradient gel electrophoresis analysis of polymerase chain reaction-amplified genes coding for 16S rRNA. Appl Environ Microbiol 1993; 59:695-700.

22 Sanguinetti CJ, Dias Neto E, Simpson AJ. Rapid silver staining and recovery of PCR products separated on polyacrylamide gels. Biotechniques 1994; 17:914-21.

23 ben Omar N, Ampe F. Microbial community dynamics during production of the Mexican fermented maize dough pozol. Appl Environ Microbiol 2000; 66:3664-73.

24 Penders J, Vink C, Driessen C, London N, Thijs C, Stobberingh E. Quantification of Bifidobacterium spp., Escherichia coli and Clostridium difficile in faecal samples of breast-fed and formula-fed infants by real-time PCR. FEMS Microbiol Lett 2005; 243:141-7.

25 Schwiertz A, Gruhl B, Lobnitz M, Michel P, Radke M, Blaut M. Development of the intestinal bacterial composition in hospitalized preterm infants in comparison with breast-fed, full-term infants. Pediatr Res 2003; 54:393-9.

26 Kirjavainen PV, Arvola T, Salminen SJ, Isolauri E. Aberrant composition of gut microbiota of allergic infants: a target of bifidobacterial therapy at weaning? Gut 2002; 51:51-5. 
27 Lodinova-Zadnikova R, Cukrowska B, Tlaskalova-Hogenova H. Oral administration of probiotic Escherichia coli after birth reduces frequency of allergies and repeated infections later in life (after 10 and 20 years). Int Arch Allergy Immunol 2003; 131:209-11.

28 Lodinova-Zadnikova R, Sonnenborn U, Tlaskalova H. Probiotics and E. coli infections in man. Vet Q 1998; 20 (Suppl. 3): S78-81.

29 Boudeau J, Glasser AL, Julien S, Colombel JF, DarfeuilleMichaud A. Inhibitory effect of probiotic Escherichia coli strain Nissle 1917 on adhesion to and invasion of intestinal epithelial cells by adherent-invasive $E$. coli strains isolated from patients with Crohn's disease. Aliment Pharmacol Ther 2003; 18:45-56.

30 Rautava S, Ruuskanen 0, Ouwehand A, Salminen S, Isolauri E. The hygiene hypothesis of atopic disease - an extended version. J Pediatr Gastroenterol Nutr 2004; 38:378-88.
31 Matricardi PM, Bonini S. High microbial turnover rate preventing atopy: a solution to inconsistencies impinging on the Hygiene hypothesis? Clin Exp Allergy 2000; 30:1506-10.

32 Wold AE. The hygiene hypothesis revised: is the rising frequency of allergy due to changes in the intestinal flora? Allergy 1998; 53:20-5.

33 Alm JS, Swartz J, Bjorksten B et al. An anthroposophic lifestyle and intestinal microflora in infancy. Pediatr Allergy Immunol 2002; 13:402-11.

34 Edwards CA, Parrett AM. Intestinal flora during the first months of life: new perspectives. Br J Nutr 2002; 88 (Suppl. 1):11-8.

35 Nadkarni MA, Martin FE, Jacques NA, Hunter N. Determination of bacterial load by real-time PCR using a broad-range (universal) probe and primers set. Microbiology 2002; 148:257-66.

36 Penders J, Thijs C, Vink C et al. Factors influencing the intestinal microbiota in early infancy. Pediatrics 2006; 118:511-21. 